\title{
Evaluation of the impact of vegetable oils on the germination of lettuce seeds (Lactuca sativa L.)
}

\author{
Sérgio Thode Filho' ${ }^{1}$, Emanuele Nunes de Lima Figueiredo Jorge ${ }^{2}$, Leonardo Corrêa de Souza ${ }^{3}$, \\ Matheus Lucas Rocha da Silva Pereira ${ }^{4}$, Raiane de Almeida Marinho Nascimento ${ }^{5}$, Ray da \\ Siqueira Pereira ${ }^{6}$, Heider Alves Franco ${ }^{7}$
}

\author{
1,2Professor at the Federal Institute of Education, Science and Technology of Rio de Janeiro - IFRJ, Campus Duque de \\ Caxias, RJ, Multidisciplinary Laboratory Waste Management - LMGR. sergio.thode@ifri.edu.br \\ ${ }^{3}$ Graduation Student at the University UNIGRANRIO, Rio de Janeiro, RJ, Multidisciplinary Laboratory Waste \\ Management - LMGR \\ 4,5,6Student of the Technical Course in Petroleum e Gas - IFRJ, Campus Duque de Caxias, RJ Multidisciplinary \\ Laboratory Waste Management - LMGR
}

7Professor at the Federal Institute of Education, Science and Technology of Rio de Janeiro - IFRJ, Campus Pinheiral, RJ, Multidisciplinary Laboratory of Agro-Environmental Technology - LAMTAA

\begin{abstract}
Vegetable oils were widely used for food production at different levels: domestic, commercial or industrial. Due to the improper discharge of its remainings in the sewage system, they becom potentially polluting for water resources and can cause many problems to wastewater treatment plants operation, provoking efficiency loss and increasing operational costs. The objective of this work was to evaluate the impact of four vegetable oils (soy, corn, canola and sunflower) on germination and development of lettuce seeds (Lactuca sativa L.). The experimental design had 7 treatments for the test group (oils) and 1 control group. The control group was composed of $4 \mathrm{~mL}$ deionized water. At the end of $120 \mathrm{~h}$ ( 5 days), the following parameters were evaluated: number of germinated seeds and length of rootlets. It was verified a negative effect on the germination rate and root growth as a function of the increase of the doses. Starting the dose with $0.1 \mathrm{~mL}$ of oil, was observed inhibition in rate of germination and root growth. All the oils studied were equally impacting to the parameters of seed germination and root growth of lettuce seeds.
\end{abstract}

Keywords: Vegetable oils, Germination, Enviroment impact.

\section{Introduction}

Vegetable oils are widely used for food production at different levels: domestic, commercial or industrial. The estimated production of vegetable oil, in Brazil, is three billion liters per year. Only $2.5 \%$ of cooking oil waste is recycled. The remaining is improperly discharge in 
the sewage system, becoming potentially polluting for water resources and can cause many problems to wastewater treatment plants operation, provoking efficiency loss and increasing operational costs. (RABELO and FERREIRA, 2008; SABESP, 2011; ABIOVE, 2016).

According to Technical Standard NBR 10.004 Solid waste - Classification (ABNT, 2004), this waste is classified as: Class II A, Not Hazardous - Not Inert.

In Brazil, waste management, such as cooking oil waste should follow the solid waste national policy - PNRS (Brazil, 2010), which does not allow its discharge into sewage pipe. However, there is no consensus about the appropriate environmental way for its disposal. The most accepted guidance is to put the oil in an enclosed container, such as a plastic bottle, to discard it in the municipal solid waste service to be landfilled. The disadvantage of this procedure is the possibility of a container leakage and a consequent environmental contamination (RABELO and FERREIRA, 2008).

Another possible source for environmental contamination comes from the fact that this type of waste can be its use as a chemical products emulsifier to spray over crops. The addition of small amounts of vegetable oils as an emulsifying agent in the spraying liquor of some crops favors the spread and absorption of herbicides (MENDONÇA et al., 2007). More recently, its use for petroleum contaminated soils remediation presented at GONG et al. (2005a and 2005b), showed that the addition of vegetable oil in contaminated sandy facilitates the degradation of more than $90 \%$ of petroleum hydrocarbons.

Tamada et al (2012) studied the bioremediation of sandy soils contaminated with vegetable oil (virgin and used) and with biodiesel. Toxicological tests (germination with lettuce seeds and avoidance test using earthworms) performed with contaminated soil samples at different treatment periods: $\mathrm{t}=$ zero, 60,120 and 180 days. Soils contaminated with biodiesel presented $50 \%$ germination inhibition at time zero and in other treatment periods. For the remaining oils, the germination inhibition increased over time, for virgin and residual vegetable oil $(20 \%$ to $12 \%)$ in 60 days, (32\% to $13 \%)$ in 120 days, $(40 \%$ to $65 \%)$ in 180 days, respectively. The germination inhibition caused by vegetable oils was attributed to the formation of toxic secondary compounds. On the other hand, in the tests with terrestrial organisms was not observed earthworm death. However, they showed weight gain in soils contaminated with vegetable oils, demonstrating that the vegetable oil and its degradation products were not toxic to them. The objective of this work was to evaluate the impact of four vegetable oils (soy, corn, canola and sunflower) on the germination and development of lettuce seeds (Lactuca sativa L.).

\section{Materials and methods}

\subsection{Vegetable oils}

Were purchased Four bottles of $1000 \mathrm{~mL}$ of virgin vegetable oils (soy, corn, canola and sunflower) of the Lisa ${ }^{\circledR}$ brand, of the same of production batch and validity up to 12.11.17.

\subsection{Seed sampling}

To perform the tests were used lettuce seeds (Lactuca sativa L.). The seeds were from ISLA PAK $^{\circledR}$ with $99.7 \%$ purity, $85 \%$ germination and validity until July / 18, directly, without any previous procedure.

\subsubsection{Phitototixicity test}

Toxicity tests about radicle germination and development using lettuce seeds (Lactuca sativa L.) were performed to evaluate both, the lethal inhibition effects on seed germination and the sub lethal effects on radicle development (SOBRERO and RONCO, 2004 and OECD, 2003). 
The experimental design had 7 treatments for the test group (oils) and 1 control group. The control group was composed of $4 \mathrm{~mL}$ deionized water. The treatments for the test group were: $0,1 \mathrm{~mL}$ oil $+3,99 \mathrm{~mL}$ of deionized water, $0,4 \mathrm{~mL}$ oil $+3,6 \mathrm{~mL}$ deionized water, $0,7 \mathrm{~mL}$ oil + $3,3 \mathrm{~mL}$ deionized water, $1 \mathrm{~mL}$ oil $+3 \mathrm{~mL}$ deionized water, $2 \mathrm{~mL}$ oil $+2 \mathrm{~mL}$ deionized water, $3 \mathrm{~mL}$ oil $+1 \mathrm{~mL}$ deionized water e $10 \mathrm{~mL}$ only oil (without added water). This procedure was used for the all oils (oil + water). For all treatments, had three replicates.

Additionally, twenty seeds of lettuce were placed in a Petri dish of $9.5 \mathrm{~cm}$ in diameter and moistened with the solution prepared according to established treatments, having as substrate a qualitative filter paper (porosity $14 \mu \mathrm{m}$ ). The Petri dishes were conditioned in a BOD incubator with photoperiod (CIENLAB and model CE-300/350-F) at a temperature of $25 \pm 2^{\circ} \mathrm{C}$ for $12 \mathrm{~h}$ light / $12 \mathrm{~h}$ dark.

\subsubsection{Phytomass assessment}

At the end of $120 \mathrm{~h}$ (5 days), the following parameters were evaluated: number of germinated seeds and length of rootlets.

In order to determine the sublethal effects, it was sought to identify the concentration of unobserved effect (NOEC) which corresponds to the highest concentration / dose of toxic agent that does not cause deleterious effect statistically significant in the organisms in the time and in the conditions of the test; and the observed effect concentration (LOEC), which corresponds to the lowest concentration / dose of toxic agent that causes statistically significant deleterious effects on organisms at the time of exposure and the test conditions (RONCO, BAEZ and GRANADOS, 2004). The determination of NOEC and LOEC were carried out from the comparison between the means of the root length.

\subsection{Statistical analysis}

The germination tests measurements and the length of rootlets were analyzed using a graduated ruler and a digital caliper. After these measurements, the parameters averages were calculated and Tukey's test used to evaluate the significance at 0.05 (5\% probability) among them (COSTA NETO, 1977; MILLER; MILLER, 1993).

All calculations and graphs presented in this work were performed by BioEstat 5.0 and SigmaPlot 12.5 software.

\section{Results and Discussion}

The average values of the germination percentage as a function of the different treatments with vegetable oils are shown in Figure 1. The control group presented 97\% germination. It was verified that from the lowest dosage administered $(0.1 \mathrm{~mL})$ there was an inhibition in the germination of $10 \%$ for both oils. To treatment with $0.4 \mathrm{~mL}$ the inhibition was of the $14 \%$ (soy and corn) and 12\% (canola and sunflower). The percentage of inhibition for treatment with $0.7 \mathrm{~mL}$ was $28 \%$ (soy and corn), and $19 \%$ (canola and sunflower). To the $1 \mathrm{~mL}$ of the soy and corn $(50 \%$ inhibition) and $44 \%$ the inhibition on germination for canola and sunflower. The same inhibitory behavior was observed for the other treatments $(2$ and $3 \mathrm{~mL})$. For the treatment with $10 \mathrm{~mL}$ the germination rate was zero. The $p$-value found for the treatments was 0.0001. Significant differences were observed between the control group and the Tukey test $(p<0.05)$. The quadratic regression describes a decreasing behavior for the germination response in relation to the different treatments with oils. 


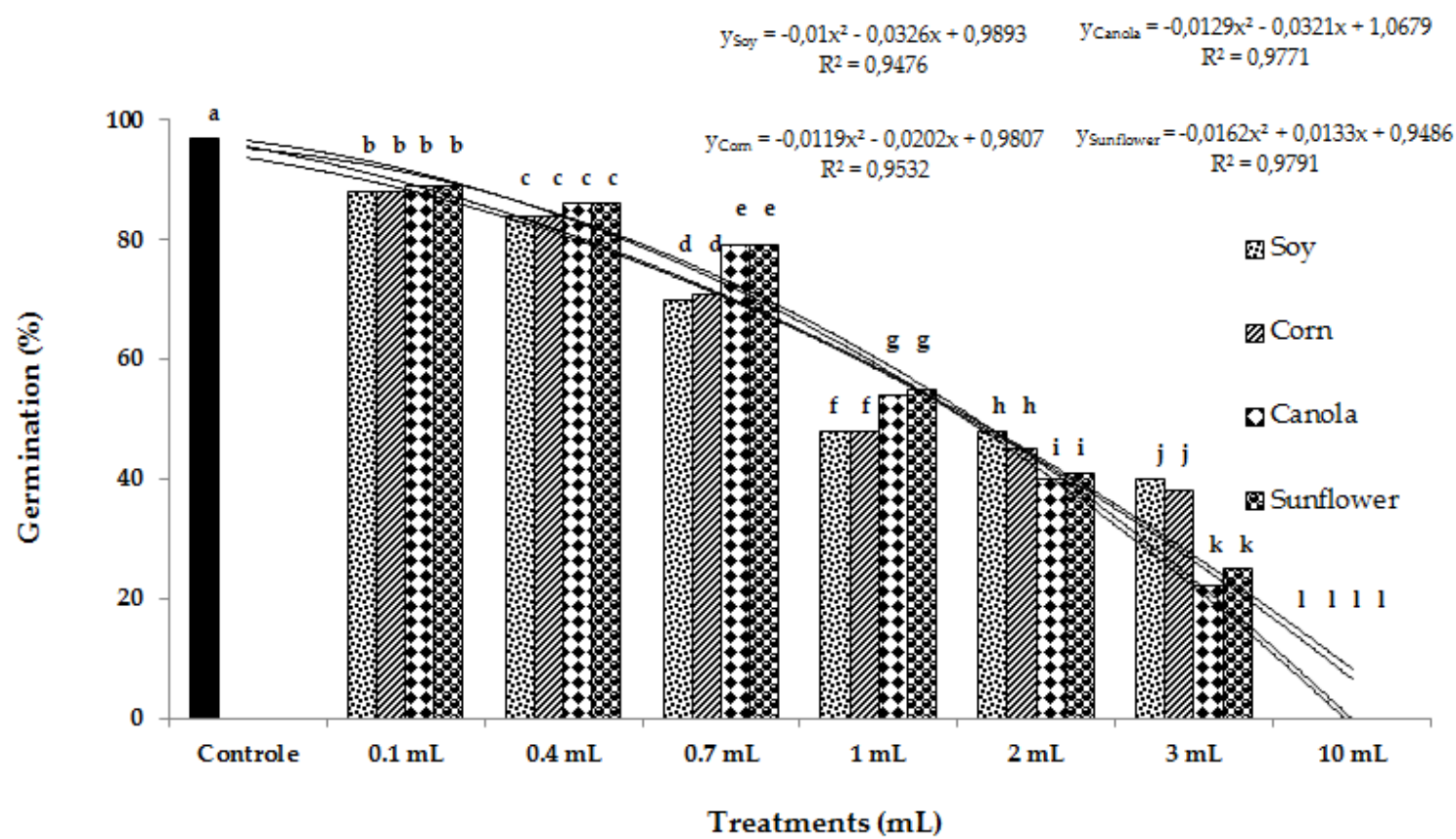

Figure 1. Evaluation of the percentage of germination of lettuce seeds (Lactuca sativa L.) contaminated with different dosages of the vegetable oil of soy, corn, colsa and sunflower. Means followed by the same lowercase letter do not differ statistically from each other by Tukey test $(\mathrm{p}<0.05)$.

According to Beweley and Black (1994), the germinated seeds percentage is regulated by internal seeds balance factors and external environmental factors, such as, light, humidity, temperature and oxygen concentration. Moreover, oily substances tend to wrap the seeds with a film, thus forming a physical barrier, preventing water and oxygen transfer, as well as stopping nutrients absorption and gas exchanges (VAUHKONEN et al., 2008; VWIOKO and FASHEMI, 2005 and NJOKU et al., 2009). In this study, the dosage above $0,7 \mathrm{~mL}$ for the all oils caused a percentage of germination below $80 \%$. That's should have been enough to wrap the seeds, making difficult to exchange gas.

Thode-Filho et al. (2017) evaluated the effect of waste vegetable oil on germination of lettuce seeds (Lactuca sativa L.) and verified that from $0.1 \mathrm{~mL}$ the germination percentage was lower than $88 \%$. These results corroborate how the present study.

The average values of the radicle length in function of the different treatments with vegetable oils are shown in Figure 2. As oils dosage was increased, the radicle growth inhibition increases (graphic 2). At $0.1 \mathrm{~mL}$ dosage, the inhibition was $23 \%$ (soy) and $20 \%$ (corn, canola and sunflower). At $0.4 \mathrm{~mL}$ dosage, the inhibition was 32\% (soy and sunflower) and $35 \%$ (corn and canola). The treatment with $0.7 \mathrm{~mL}$ dosage presented the worst performance for sunflower oil (42\% of inhibition). From $1 \mathrm{~mL}$ all doses showed inhibition of growth of $70 \%$. For the treatment with $10 \mathrm{~mL}$ the radicle length rate was zero. The p-value found for the treatments was 0.0003 . Significant differences were observed between the control group and the Tukey test $(p<0.05)$. The quadratic regression describes a decreasing behavior for the radicle length response in relation to the different treatments with oils. 


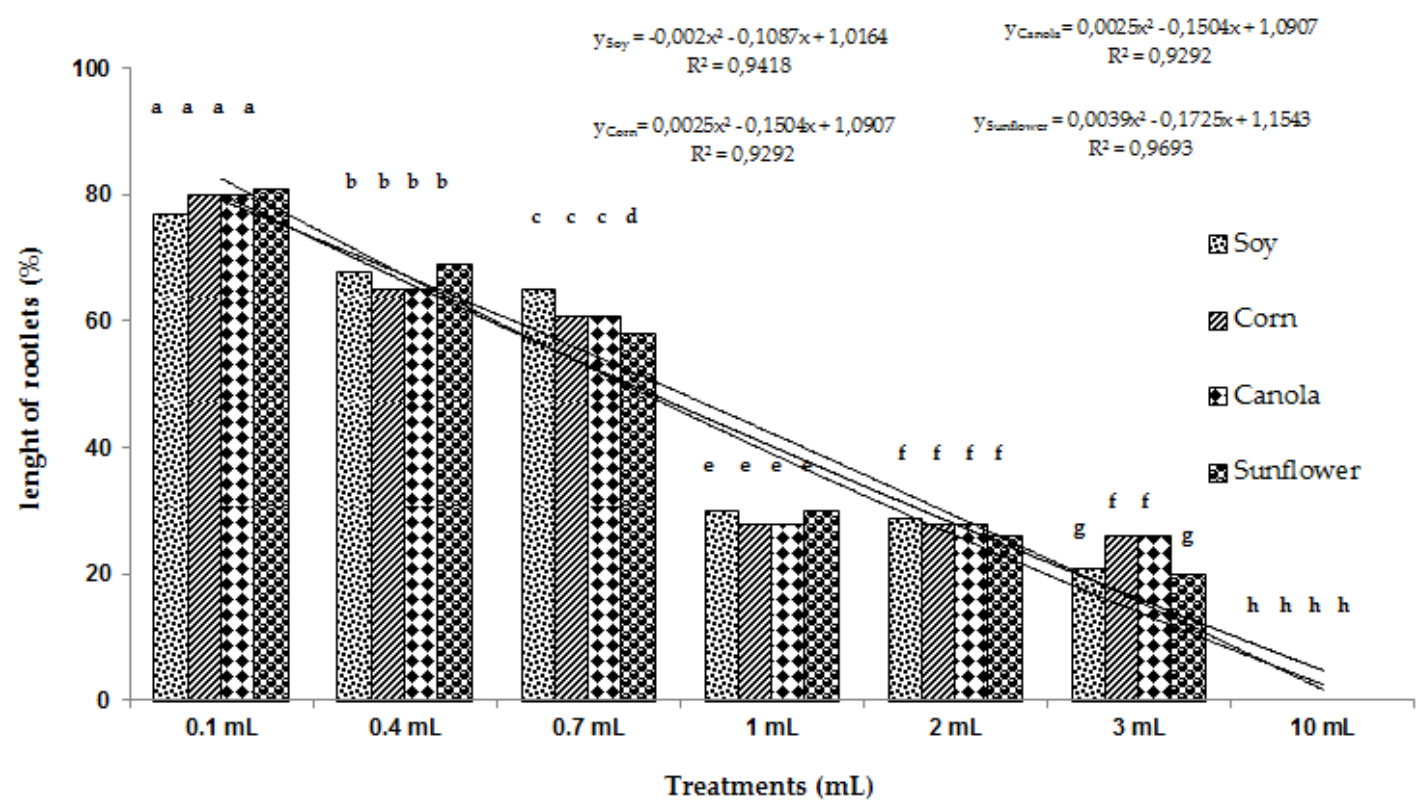

Figure 2. Evaluation of the radicle length of lettuce seeds (Lactuca sativa L.) contaminated with different dosages of the vegetable oil of soy, corn, colsa and sunflower. Means followed by the same lowercase letter do not differ statistically from each other by Tukey test $(\mathrm{p}<0.05)$.

Was observed that the radicle growth was more sensitive to oils than the germination. The evaluation of oils effect on root elongation may reflect compounds toxicity even at very low concentrations (SOBRERO e RONCO, 2004; TAMADA et al., 2012), which are not sufficient to inhibit germination but may delay or inhibit the root elongation process depending on this compounds mode and site of action. In this study, the very low solubility of oils in water showed to be sufficient to cause root elongation inhibition.

Harmful effects were observed for seed germination and radicular length from the lowest dosage administered for all the oils under study. Therefore, the LOEC was determined with 0.1 $\mathrm{mL}$. It was not possible to identify NOEC because the lowest dose was able to promote subtly perceptible effects by inhibiting the development of the radicle.

\section{Conclusion}

The vegetable oils are classified as a not hazardous, not inert residue. However, its final destination should employ some special measures of collection and protection of the environment. It was verified a negative effect on the germination rate and root growth as a function of the increase of the doses. Starting the dose with $0.1 \mathrm{~mL}$ of oil, was observed inhibition in rate of germination and root growth. All the oils studied were equally impacting to the parameters of seed germination and root growth of lettuce seeds.

\section{References}

ABIOVE. Associação Brasileira das Indústrias de Óleos Vegetais. 2016. Disponível em: <http:// www.abiove.com.br/menu_br.html>. Acesso em: 18 abr 2017.

ASSOCIAÇÃO BRASILEIRA DE NORMAS TÉCNICAS. NBR 10.004: Resíduos sólidos Classificação. Rio de Janeiro: 2004a.

BEWLEY, J. D.; BLACK, M. Seeds: Physiology of Development and Germination. 2 ed. Plenum Press, New York, 1994. 
BRASIL. Presidência da República. Lei no 12.305, de 2 de agosto de 2010. Institui a Política Nacional de Resíduos Sólidos; altera a Lei no 9.605, de 12 de fevereiro de 1998; e dá outras providências. Diário Oficial da [União]. Brasília, DF, 3 agosto 2010.

COSTA NETO, P. L. O. Estatística. São Paulo: Edgard Blücher, 1977. 264p.

GONG, Z. et al. Dissolution and removal of PAHs from a contaminated soil using sunflower oil. Chemosphere, v. 58, n. 3, p. 291-298, 2005 a.

GONG, Z. et al. Influence of soil moisture on sunflower oil extraction of polycyclic aromatic hydrocarbons from a manufactured gas plant soil. Science of the total environment, v. 343, n. 1, p. 51-59, 2005b.

MENDONÇA, C.G. DE; RAETANO, C.G.; MENDONÇA, C.G. DE. Tensão superficial estática de soluções aquosas com óleos minerais e vegetais utilizados na agricultura. Engenharia Agrícola, Jaboticabal. 2007; 27: 16-23.

MILLER, J.C. \& MILLER, J.N. Statistics for analytical chemistry. 3a ed. Chichester: Ellis Horwood. 233p., 1993.

NJOKU, K.L.; AKINOLA, M.O; TAIWO, B.G.. Effect of gasoline diesel fuel mixture on the germination and the growth of Vigna unguiculata (Cowpea). African Journal of Environmental Science and Technology, v. 3, n. 12, 2009.

ORGANIZATION FOR ECONOMIC COOPERATION AND DEVELOPMENT - OECD Terrestrial Plant Test: 208: Seedling Emergence and Seedling Growth Test. Guideline for the Testing of Chemicals Proposal for Updating Guideline 208, 2003.

RABELO, R. A.; FERREIRA, O. M. Coleta seletiva de óleo residual de fritura para aproveitamento indústria. 2008. Disponível em: <http://www.ucg.br>. Acesso em: 14 abr. 2017.

RONCO, A.; BÁEZ, M. C. D.; GRANADOS, Y. P. Em Ensayos Toxicológicos y Métodos de Evaluación de Calidad de Aguas - Estandarización, Intercalibración, Resultados y Aplicaciones; Morales, G. C., ed.; Centro Internacional de Investigaciones para el Desarrollo: Ottawa, 2004, cap. 1.

SABESP. Reciclagem de óleo de cozinha, 2011. Disponível em: <http://site.sabesp.com.br $>$. Acesso em: 17 abr. 2017.

SOBRERO, M. C.; RONCO, A. Ensayo de toxicidad aguda con semillas de lechuga (Lactuca sativa L.). In: Ensayos toxicológicos y métodos de evaluación de calidad de aguas. Ottawa, Canadá, IDRC/IMTA. Ed., v. 4, p. 71-79, 2004.

TAMADA, I. S.; MONTAGNOLLI, R. N.; LOPES, P. R. M.; BIDOIA, E. D. Toxicological evaluation of vegetable oils and biodiesel in soil during the biodegradation process. Brazilian Journal of Microbiology. p. 1576-1581, 2012.

THODE-FILHO, S., PAIVA, J.L. de, FRANCO, H.A., PEREZ, D.V., MARQUES, M.R.C. de. Environmental impacts caused by residual vegetable oil In the soil-plant system. Ciência e Natura Journal, (2017). [no prelo] 
VAUHKONEN, V.; LAUHANEN, V.; SUOJARANTA, S. The phytotoxic effects and biodegradability of stored rapeseed oil and rapeseed oil methyl ester. Agric. Food Sci. v. 20, n. 2, p. 131-142, 2008.

VWIOKO, D.E.; FASHEMI, D.S. 2005. Growth response of Ricinus communis L (Castor Oil) in spent lubricating oil polluted soil. Journal of Applied Sciences and Environmental Management, v. 9, n. 2, p. 73-79, 2005. 